\title{
Aplikasi Kompos Dengan Aktivator Effective Microorganisms 4 (EM 4) Dan Pupuk Organik Cair NASA Pada Pertumbuhan Bibit Batang Bawah Tanaman Karet (Hevea brasiliensis)
}

\section{Application of Compost With Effective Microorganisms Activator 4 (EM 4) And Nasa Liquid Organic Fertilizer On Growth Of Rubber Trunk Bottom Plant (Hevea brasiliensis)}

\author{
Wandi Fahrin ${ }^{1}$, Mahdalena ${ }^{2}$, Hamidah ${ }^{2}$ \\ ${ }^{1}$ Alumni Program Studi Agroteknologi, Fakultas Pertanian, Universitas Widya Gama Mahakam \\ ${ }^{2}$ Tenaga Pendidik Program Studi Agroteknologi, Fakultas Pertanian, Universitas Widya Gama Mahakam \\ Jl. KH. Wahid Hasyim, Sempaja, Samarinda, Kalimantan Timur, Indonesia \\ email : fwandi@gmail.com,mahdalena@uwgm.ac.id, hamidah@uwgm.ac.id
}

Diterima : 17 Mei 2017 Disetujui : 2 Juni 2017

\begin{abstract}
Application of Compost With Effective Microorganisms Activator 4 (EM 4) And NASA Fluid Organic Fertilizer At Growth Of Rubber Trunk Bottom Plant (Hevea brasiliensis). This study aims to determine the effect of application of compost fertilizer with activator Effective Microorganisms 4 (EM 4) and the effect of Nasa liquid organic fertilizer application on the growth of rootstock seedling of rubber plant. The study was conducted for 3 months starting from May 5 to August 5, 2015 Loa Janan Ulu Village Kutai Kertanegara Regency. The study used Randomized Block Design (RAK) with $4 \times 4$ factorial experiment with 3 replications. The first factor is the application of compost treatment consisting of 4 levels, namely: $k 0$ Tanah (topsoil), $k 1=$ Soil: Compost $=1: 1, k 2=$ Soil: Compost $=1: 2, k 3=$ Soil: Compost $=1: 3$. While the second factor is the application of liquid organic fertilizer NASA consisting of 4 levels, namely: $p 0=$ Control, $p 1=2 \mathrm{ml} / L$ water, $p 2=4 \mathrm{ml} / L$ water, $p 3=6 \mathrm{ml} / L$ water. The result of variance indicated that application of compost fertilizer had a very significant effect on the height of 3 month crop, the increase of stem diameter month 2, month 3, the increase of monthly leaf number 2, month 3. Furthermore significant effect on the increase of plant height month 1, month 2, Stem diameter month 1, and month leaf number increase 1. Application of NASA $(P)$ liquid organic fertilizer had a very significant effect on the parameters of plant height increase in month 2, month, 3, month stem diameter 2, month 3, Month 3. Then the real effect on parameters of plant height month month 1 , and the increase of number of leaves month 1 . For interaction application of Compost Fertilizer and organic fertilizer Nasa $(K x P)$ no significant effect on parameters of plant height increase month 1 , month 2 , month 3 , the increase of number of leaves month 1 , month 2 , month 3 , the increase of stem diameter month 1, month 2 and month 3.
\end{abstract}

Keywords: Effective Microorganisms 4, Liquid Fertilizer Nasa and Rubber Plants

\section{PENDAHULUAN}

Tanaman karet (Hevea brasiliensis) merupakan tanaman perkebunan yang bernilai ekonomis tinggi. Tanaman tahunan ini dapat disadap getah karetnya pertama kali pada umur tahun ke-5. Dari getah tanaman karet (lateks) tersebut bisa diolah menjadi lembaran karet (sheet), bongkahan (kotak), atau karet remah (crumb rubber) yang merupakan bahan baku industri karet. Kayu tanaman karet, bila kebun karetnya hendak diremajakan, juga dapat digunakan untuk bahan bangunan, misalnya untuk membuat rumah, furniture dan lain-lain (Badan Penelitian dan Pengembangan Pertanian, 2005).

Prospek industri karet masih terbuka luas sejalan dengan bergesernya konsumsi karet dunia dari Eropa dan Amerika ke Asia. Untuk itu, industri karet harus mampu berproduksi maksimal apalagi pasokan karet domestik semakin besar pasca pembatasan ekspor. Indonesia memiliki areal karet paling luas di dunia, yaitu 3,4 juta ha dengan produksi karet per tahun 2,7 juta ton. Meski begitu, produktivitasnya hanya 1,0 ton/ha, lebih rendah daripada Malaysia (1,3 ton/ha) dan Thailand (1,9 ton/ha). Produksi karet di Indonesia, Thailand, dan Malaysia berkontribusi $85 \%$ dari total produksi dunia. Namun, Indonesia memiliki kesempatan paling besar untuk memimpin industrikaret dunia. Harga karet dunia saat ini masih mengalami tekanan akibat turunnya permintaan. Oleh karena itu, tiga negara utama produsen karet alam bersepakat menahan penurunan harga dengan mengurangi ekspor. Artinya pasokan karet di dalam negeri akan semakin melimpah (Kemenperin, 2012).

Khusus untuk daerah Kalimantan Timur sendiri prospek karet sangat menjanjikan. Luas areal pertanaman karet tercatat seluas 103.117 $\mathrm{Ha}$ yang terdiri dari areal perkebunan rakyat 89.341 Ha, perkebunan besar negara sebesar 709 Ha dan perkebunan besar swasta $13.067 \mathrm{Ha}$ dengan produksi seluruhnya berjumlah 59.963 ton karet kering. Produk tersebut pada umumnya 
dipasarkan ke Banjarmasin untuk kebutuhan pabrik Crumb Rubber. Pusat pertanaman karet terbesar berada di Kabupaten Kutai Barat (Kecamatan Melak dan Barong Tongkok) yang dikembangkan oleh petani pekebun melalui proyek TCSSP bantuan dari Bank Pembangunan Asia (Asian Development Bank/ADB) (Dinas Perkebunan Kaltim, 2014).

Produksi lateks yang dihasilkan di negara Indonesia masih tergolong rendah. Salah satu kendala yang sangat berpengaruh dalam produksi lateks di Indonesia adalah ketersediaan lahan untuk perkebunan karet. Lahan pertanian yang ada di Indonesia semakin berkurang seiring dengan semakin padatnya jumlah penduduk. Usaha yang telah dilakukan pemerintah dalam meningkatkan produksi diantaranya melakukan peremajaan atau perluasan lahan tanam menggunakan klon-klon yang unggul dan baru. Sasaran yang dituju dalam usaha tersebut adalah tanaman karet rakyat, sedangkan untuk tanaman karet perkebunan ditempuh melalui perbaikan sistem eksploitasi. Untuk mendapatkan bibit tanaman yang bagus, selama ini dilakukan dengan cara okulasi bibit tanaman karet. Pada proses pembuatan bibit okulasi, diperlukan bibit batang bawah (stock) dan bibit batang atas (scion) (Eko dkk, 2013).

Untuk memenuhi kebutuhan bibit batang bawah tanaman karet yg baik dapat diupayakan dengan menggunakan klon-klon anjuran. Beberapa klon anjuran untuk batang bawah adalah GT 1, AVROS 2037, dan PB 260. Kenyataan di lapangan menunjukan bahwa pelaksanaan menghasilkan bibit batang bawah tanaman karet dilakukan hanya sebatas pembangunan teknis yang mencakup persiapan tanah pembibitan, penanganan benih, perkecambahan, penanaman kecambah, serta usaha pemeliharaan tanaman $\mathrm{d}$ pembibitan. Untuk mendapatkan bibit batang bawah yang baik perlu juga adanya pemupukan. Pengunaan pupuk dalam pemeliharan bibit sudah merupakan kebutuhan vital bagi petani karet dengan maksud untuk mendapatkan pertumbuhan bibit yang baik atau sesuai dengan yang diharapkan. Salah satu usaha agar dapat mendapatkan pertumbuhan bibit batang bawah yang baik yaitu dengan pupuk kompos.

\section{BAHAN DAN METODE}

Penelitian dilaksanakan selama 3 bulan terhitung mulai tanggal 5 Mei - 5 Agustus 2015 Desa Loa Janan Ulu Kabupaten Kutai Kertanegara. Bahan yang digunakan yaitu ; sekam padi, dedak, pupuk kandang, tanah
Pemupukan dengan kompos juga mempunyai maksud mencapai kondisi dimana tanah memungkinkan tanaman tumbuh dengan sebaik-baiknya. Keadaan tanah yang baik berarti pula, bahwa tanaman dapat dengan mudah menyerap makanan melalui akarnya yang kuat, dibanding dengan jika pertumbuhannya kurang baik maka pemberian kompos dalam pemupukan dengan sendirinya akan memberikan hasil yang lebih baik. Kompos juga mempunyai kelebihan diantaranya adalah dapat memperbaiki produktiftas tanah, dan dapat meningkatkan kesuburan tanah (Yuwono, 2005).

Dalam proses pengomposan diperlukan aktivator untuk mempercepat proses pelapukan atau penghancuran bahan-bahan kompos, yaitu dengan menggunakan Aktivator Effective Microorganisms 4 (EM 4). Golongan utama penyusun Effective Microorganisms 4 (EM 4) yaitu bakteri fotosintetik, Lactobacillus sp., Streptomyces sp., ragi, dan Actinomycetes. Bakteri ini lah yang membantu mempercepat pengomposan (Djuarnani et al. 2005).

Untuk mendukung pertumbuhan tanaman karet di pembibitan diperlukan pasokan berupa unsur hara. Salah satu pupuk yang mengandung unsur hara yang lengkap adalah pupuk organik cair NASA. Kegunaan daripada pupuk organik NASA adalah sebagai mempercepat proses pertumbuhan tanaman, memacu dan meningkatkan pembungaan, pembuahan, mengurangi kerontokan bunga dan buah, membantu pertumbuhan tunas, membantu pertumbuhan akar, memacu pembesaran umbi serta meningkatkan keawetan hasil panen. Selain itu juga pupuk organik nasa dapat meningkatkan kuantitas dan kualitas produksi tanaman serta kelestarian lingkungan, menjadikan tanah yang keras berangsur - angsur menjadi gembur (Wunungga, 2009).

Dari penjelasan di atas dapatlah dilihat bahwa pupuk mempunyai peranan penting dalam mendukung pertumbuhan bibit batang bawah tanaman karet, untuk dapat menghasilkan bibit batang bawah tanaman karet yang baik maka perlu dilakukan penelitian mengenai Aplikasi Kompos Dengan Aktivator Effective Microorganisms 4 (EM 4) dan Pupuk Organik Cair NASA Pada Pertumbuhan Bibit Batang Bawah Tanaman Karet (Hevea brasiliensis).

(topsoil), Effective Microorganisms 4 (EM 4), pupuk organik cair NASA, gula aren dan bibit batang bawah tanaman karet.. Penelitian menggunakan Rancangan Acak Kelompok (RAK) dengan percobaan faktorial 4 x 4 dengan 3 ulangan. Faktor pertama yaitu perlakuan 
aplikasi kompos yang terdiri dari 4 taraf, yaitu: k0 Tanah (topsoil), $\mathrm{k} 1=$ Tanah : Kompos $=1$ : $1, \mathrm{k} 2=$ Tanah $:$ Kompos $=1: 2, \mathrm{k} 3=$ Tanah : Kompos $=1: 3$. Sedangkan Faktor kedua yaitu aplikasi pupuk organik cair NASA yang terdiri dari 4 taraf, yaitu : p0 $=$ Kontrol, $\mathrm{p} 1=2 \mathrm{ml} / \mathrm{L}$ air, p2 $=4 \mathrm{ml} / \mathrm{L}$ air, p3 $=6 \mathrm{ml} / \mathrm{L}$ air. Pelaksanaan penelitian meliputi : persiapan lahan, pembuatan pupuk kompos, persiapan bibit batang bawah tanaman karet, seleksi bibit, persiapan Media tanam, pemindahan bibit ke polybag, pemupukan, pemeliharaan (penyiraman, penyiangan dan penyulaman. Pengambilan data meliputi ; pertambahan tinggi tanaman, pertambahan diameter batang tanaman dan pertambahan jumlah daun. Data di analisis dengan menggunakan sidik ragam, apabila ada pengaruh maka dilakukan Uji lanjutan dengan menggunakan Uji Beda Nyata Terkecil ( BNT ) pada taraf $5 \%$ untuk membandingkan dua ratarata perlakuan.

\section{HASIL DAN PEMBAHASAN}

\section{Pengaruh Pupuk Kompos}

Tabel 1. Pengaruh Pupuk Kompos (K) Terhadap Pertambahan Rata-Rata Tinggi Tanaman (cm)

\begin{tabular}{cccc}
\hline Perlakuan Pupuk & \multicolumn{3}{c}{ Tinggi tanaman } \\
\cline { 2 - 4 } Kompos & Bulan ke 1 & Bulan ke 2 & Bulan ke 3 \\
\hline $\mathrm{k}_{0}$ & $26,50 \mathrm{c}$ & $46,50 \mathrm{~d}$ & $66,00 \mathrm{c}$ \\
$\mathrm{k}_{1}$ & $32,50 \mathrm{a}$ & $51,25 \mathrm{~b}$ & $70,00 \mathrm{~b}$ \\
$\mathrm{k}_{2}$ & $31,00 \mathrm{~b}$ & $55,50 \mathrm{a}$ & $81,25 \mathrm{a}$ \\
$\mathrm{k}_{3}$ & $27,50 \mathrm{c}$ & $48,50 \mathrm{c}$ & $67,50 \mathrm{c}$ \\
\hline
\end{tabular}

Keterangan : Angka yang diikuti huruf yang sama menyatakan tidak berbeda nyata pada BNT 5\% (BNT $\mathrm{k}=1,10)$ pertambahan tinggi tanaman umur bulan ke 1 , pada $(\mathrm{BNT} \mathrm{k}=1,58)$ pertambahan tinggi tanaman umur bulan ke 2, dan pada BNT 5\% (BNT k =2,11) pertambahan tinggi tanaman umur bulan ke 3

Tabel 2. Pengaruh Pupuk Kompos (K) Terhadap Pertambahan Rata-Rata Diameter Batang (cm)

\begin{tabular}{cccc}
\hline Perlakuan Pupuk & \multicolumn{3}{c}{ Diameter Batang } \\
\cline { 2 - 4 } Kompos & Bulan ke 1 & Bulan ke 2 & Bulan ke 3 \\
\hline $\mathrm{k}_{0}$ & $1,22 \mathrm{c}$ & $2,69 \mathrm{c}$ & $3,76 \mathrm{c}$ \\
$\mathrm{k}_{1}$ & $1,48 \mathrm{~b}$ & $2,98 \mathrm{~b}$ & $4,73 \mathrm{~b}$ \\
$\mathrm{k}_{2}$ & $1,61 \mathrm{a}$ & $3,38 \mathrm{a}$ & $5,04 \mathrm{a}$ \\
$\mathrm{k}_{3}$ & $1,60 \mathrm{a}$ & $2,96 \mathrm{~b}$ & $4,67 \mathrm{~b}$ \\
\hline
\end{tabular}

Keterangan : Angka yang diikuti huruf yang sama menyatakan tidak berbeda nyata pada BNT 5\% (BNT $\mathrm{k}=0,07)$ pertambahan diameter batang umur bulan ke 1 , pada $(\mathrm{BNT} \mathrm{k}=0,08)$ pertambahan diameter batang umur bulan ke 2, dan pada BNT 5\% $(\mathrm{BNT} \mathrm{k}=0,14)$ pertambahan diameter batang umur bulan ke 3

Tabel 3. Pengaruh Pupuk Kompos (K) Terhadap Pertambahan Rata-Rata Pertambahan Jumlah Daun (helai)

\begin{tabular}{cccc}
\hline Perlakuan Pupuk & \multicolumn{3}{c}{ Jumlah Daun } \\
\cline { 2 - 4 } Kompos & Bulan ke 1 & Bulan ke 2 & Bulan ke 3 \\
\hline $\mathrm{k}_{0}$ & $17,00 \mathrm{c}$ & $30,00 \mathrm{c}$ & $45,50 \mathrm{~d}$ \\
$\mathrm{k}_{1}$ & $18,25 \mathrm{c}$ & $29,75 \mathrm{c}$ & $48,50 \mathrm{c}$ \\
$\mathrm{k}_{2}$ & $25,00 \mathrm{a}$ & $43,50 \mathrm{a}$ & $69,25 \mathrm{a}$ \\
$\mathrm{k}_{3}$ & $22,50 \mathrm{~b}$ & $37,75 \mathrm{~b}$ & $58,50 \mathrm{~b}$ \\
\hline
\end{tabular}

Keterangan : Angka yang diikuti huruf yang sama menyatakan tidak berbeda nyata pada BNT 5\% (BNT $\mathrm{k}=1,32)$ pertambahan diameter batang umur bulan ke 1 , pada $(\mathrm{BNT} \mathrm{k}=1,77)$ pertambahan diameter batang umur bulan ke 2, dan pada BNT 5\% (BNT k $=2,71)$ pertambahan diameter batang umur bulan ke 3

Hasil sidik ragam menunjukkan bahwa aplikasi pupuk Kompos berpengaruh sangat nyata terhadap pertambahan tinggi tanaman bulan 3 , pertambahan diameter batang bulan 2 , bulan 3, jumlah daun bulan 2, bulan 3 .
Selanjutnya berpengaruh nyata pada pertambahan tinggi tanaman bulan 1 , bulan 2 , pertambahan diameter batang bulan 1, dan pertambahan jumlah daun bulan 1.Hal ini diduga pupuk kompos yang di aplkasikan untuk 
pertumbuhan bibit batang bawah tanaman karet di serap secara baik oleh tanaman. Hal ini disebabkan kebutuhan unsur hara terutama $\mathrm{N}, \mathrm{P}$ dan $\mathrm{K}$ telah terpenuhi pada saat tanaman memerlukan unsur tersebut. Kandungan pupuk kompos meliputi N, P, K, yang semuanya dapat diserap oleh seluruh bagian tanaman mulai dari daun sampai ke akar. Menurut Harjadi (2003), bahwa pemberian pupuk kompos merupakan faktor utama yang sangat penting dalam pemupukan, agar efektif pupuk harus diberikan di tempat dan disaat tanaman memerlukan. Ditambahkan Harjadi (2003), mengemukakan bahwa dengan membesarnya sel tanaman maka akan terbentuk vakuola sel yang besar yang mampu untuk menyerap air dalam jumlah yang banyak, sehingga makin bertambahnya jumlah dan ukuran sel tanaman, maka pembentukan protoplasma tanaman juga akan bertambah. Selanjutnya hal ini akan berpengaruh terhadap tinggi, diameter batang tanaman yang makin meningkat. Menurut Musnawar dan Ismawati (2005), pupuk kompos selain dapat menambah unsur hara kedalam tanah juga dapat meningkatkan humus, memperbaiki struktur tanah dan mendorong kehidupan jasad renik dalam tanah. Kandungan hara yang terdapat dalam pupuk Kompos rata-rata 0,5\% N; 0,25\% $\mathrm{P}_{2} \mathrm{O}_{5}$; dan $0,5 \% \quad \mathrm{~K}_{2} \mathrm{O}$. Disamping unsur-unsur tersebut pupuk Kompos juga mengandung Karbon, Magnesium, dan Belerang, dan unsurunsur mikro lainnya. Pupuk Kompos mempunyai efek residu, yaitu haranya dapat secara berangsur-angsur menjadi bebas dan tersedia bagi tanaman. Ditambahkan oleh Sutedjo (2006), dengan adanya pupuk Kompos maka tanah akan mampu menahan banyak air, sehingga memudahkan akar-akar menyerap zatzat makanan bagi pertumbuhan dan perkembangan tanaman.

\section{Pengaruh Pupuk Organik Cair NASA}

Tabel 4. Pengaruh Pupuk Organik Cair Nasa (P) Terhadap Pertambahan Rata-Rata Tinggi Tanaman (cm)

\begin{tabular}{cccc}
\hline \multirow{2}{*}{ Perlakuan POC Nasa } & \multicolumn{3}{c}{ Tinggi tanaman } \\
\cline { 2 - 4 } & Bulan ke 1 & Bulan ke 2 & Bulan ke 3 \\
\hline $\mathrm{p}_{0}$ & $27,25 \mathrm{c}$ & $44,75 \mathrm{c}$ & $62,00 \mathrm{~d}$ \\
$\mathrm{p}_{1}$ & $28,50 \mathrm{~b}$ & $48,50 \mathrm{~b}$ & $67,75 \mathrm{c}$ \\
$\mathrm{p}_{2}$ & $33,75 \mathrm{a}$ & $59,00 \mathrm{a}$ & $83,75 \mathrm{a}$ \\
$\mathrm{p}_{3}$ & $28,00 \mathrm{c}$ & $49,50 \mathrm{~b}$ & $71,25 \mathrm{~b}$ \\
\hline
\end{tabular}

Keterangan : Angka yang diikuti huruf yang sama menyatakan tidak berbeda nyata pada BNT 5\% (BNT $\mathrm{p}=1,10)$ pertambahan tinggi tanaman umur bulan ke 1 , pada (BNT $\mathrm{p}=1,58)$ pertambahan tinggi tanaman umur bulan ke 2 , dan pada BNT 5\% (BNT p $=2,11)$ pertambahan tinggi tanaman umur bulan ke 3

Tabel 5. Pengaruh Pupuk Organik Cair Nasa (P) Terhadap Pertambahan Rata-Rata Diameter Batang (cm)

\begin{tabular}{cccc}
\hline \multirow{2}{*}{ Perlakuan POC Nasa } & \multicolumn{3}{c}{ Diameter Batang } \\
\cline { 2 - 4 } & Bulan ke 1 & Bulan ke 2 & Bulan ke 3 \\
\hline $\mathrm{p}_{0}$ & 1,29 & $2,55 \mathrm{~d}$ & $3,86 \mathrm{~d}$ \\
$\mathrm{p}_{1}$ & 1,42 & $2,90 \mathrm{c}$ & $4,25 \mathrm{c}$ \\
$\mathrm{p}_{2}$ & 1,69 & $3,45 \mathrm{a}$ & $5,28 \mathrm{a}$ \\
$\mathrm{p}_{3}$ & 1,50 & $3,11 \mathrm{~b}$ & $4,82 \mathrm{~b}$ \\
\hline
\end{tabular}

Keterangan : Angka yang diikuti huruf yang sama menyatakan tidak berbeda nyata pada (BNT $p=0,08)$ pertambahan diameter batang umur bulan ke 2, dan pada BNT 5\% (BNT p $=0,14)$ pertambahan diameter batang umur bulan ke 3

Tabel 6. Pengaruh Pupuk Organik Cair Nasa (P) Terhadap Pertambahan Rata-Rata Pertambahan Jumlah Daun (helai)

\begin{tabular}{cccc}
\hline \multirow{2}{*}{ Perlakuan POC Nasa } & \multicolumn{3}{c}{ Jumlah Daun } \\
\cline { 2 - 4 } & Bulan ke 1 & Bulan ke 2 & Bulan ke 3 \\
\hline $\mathrm{p}_{0}$ & $16,50 \mathrm{~d}$ & $28,25 \mathrm{~d}$ & $44,75 \mathrm{~d}$ \\
$\mathrm{p}_{1}$ & $19,75 \mathrm{c}$ & $32,50 \mathrm{c}$ & $52,25 \mathrm{c}$ \\
$\mathrm{p}_{2}$ & $24,50 \mathrm{a}$ & $43,00 \mathrm{a}$ & $66,75 \mathrm{a}$ \\
$\mathrm{p}_{3}$ & $22,00 \mathrm{~b}$ & $37,25 \mathrm{~b}$ & $58,00 \mathrm{~b}$ \\
\hline
\end{tabular}

Keterangan : Angka yang diikuti huruf yang sama menyatakan tidak berbeda nyata pada BNT 5\% (BNT $\mathrm{k}=1,32)$ pertambahan diameter batang umur bulan ke 1 , pada $(\mathrm{BNT} \mathrm{k}=1,77)$ pertambahan diameter batang umur bulan ke 2, dan pada BNT 5\% (BNT k $=2,71)$ pertambahan diameter batang umur bulan ke 3 
Hasil analisis sidik ragam menunjukkan bahwa aplikasi pupuk organik cair NASA (P) berpengaruh sangat nyata pada parameter tinggi tanaman bulan 2, bulan 3 diameter batang bulan 2, bulan 3, jumlah daun bulan 2, bulan 3 Kemudian berpengaruh nyata pada parameter pertambahan tinggi tanaman bulan bulan 1, dan pertambahan jumlah daun bulan 1 . Hal inididuga pupuk organik cair NASA mengandung hormon auksin, giberelin dan sitokininyang bermanfaat dalam memacu pertumbuhan. Menurut Lingga (2004), fungsi auksin pada tanaman membantu proses terbentuknya akar, merangsang pertumbuhan tanaman dan mematahkan dominansi pucuk/apikal kondisi dimana pucuk tanaman atau akar tidak mau berkembang. Sitokinin memegang peranan penting dalam

\section{Pengaruh Interaksi Pupuk Kompos dan Pupuk Organik Cair NASA}

Hasil analisis sidik ragam menunjukkan bahwa interaksi aplikasi pupuk Kompos dan aplkasi pupuk organik cair NASA tidak berpengaruh nyata terhadap parameter tinggi tanaman bulan 1 , bulan 2 , bulan 3 , pertambahan diameter batang bulan 1 , bulan 2, bulan 3, pertambahan jumlah daun bulan 1 , bulan 2 , dan bulan 3.Hal ini diduga karena perlakuan konsentrasi pupuk organik cair NASA dan Kompos terhadap tanaman karet tidak terdapat

\section{KESIMPULAN}

1. Aplikasi pupuk kompos yang terbaik terhadap pertambahan tinggi tanaman, pertambahan diameter batang dan pertambahan jumlah daun, pada bibit batang bawah tanaman karet dicapai oleh perlakuan $\mathrm{k}_{2}$ (Tanah : Kompos $=1: 2$ ).

2. Aplikasi pupuk organik cair NASA yang terbaik terhadap pertambahan tinggi tanaman,

\section{DAFTAR PUSTAKA}

Abidin, Z. 2001. Dasar-dasar Pengetahuan Tentang Zat Pengatur Tumbuh. Angkasa. Bandung. $36 \mathrm{hlm}$.

Anonim. 2006. Buletin Penggunaan Pupuk Organik Cair NASA. Natural Nusantara. Yogyakarta.

Badan Penelitian dan Pengembangan pertanian. 2008. Teknologi Budidaya Karet. Departemen Pertanian. 42 hal. peroses pembelahan dan perbesaran sel, sehingga akan memacu kecepatan pertumbuhan tanaman, pembentukan tunas-tunas baru dan menaikan tingkat mobilitas unsur-unsur dalam tanah. Giberelin mematahkan dormansi atau hambatan pertumbuhan tanaman sehingga tanaman dapat tumbuh normal dengan cara mempercepat proses pembelahan sel. Menurut Abidin, Z (2001), umumnya pemberian pupuk dan hormon melalui daun lebih cepat penyerapan unsur haranya dibandingkan melalui akar, karena itu cara ini cocok untuk mengaplikasikan pupuk dan hormon yang sulit diserap akar, sebab efek pemupukan dapat langsung tampak dalam beberapa hari setelah pemupukan, selain itu tanah juga tidak mengalami kerusakan.

hubungan yang saling mempengaruhi, sehingga masing-masing berpengaruh secara terpisah satu sama lainnya. Hal ini sesuai pendapat Steel dan Torrie (1991), bahwa bila pengaruh interaksi berbeda tidak nyata, maka disimpulkan bahwa diantara faktor-faktor perlakuan tersebut bertindak bebas.

pertambahan diameter batang dan pertambahan jumlah daun yang terbaik dicapai oleh $\mathrm{p}_{2}$ (4 ml/L air).

3. Interaksi aplikasi pupuk kompos dan aplikasi pupuk organik cair NASA (KxP) tidak berpengaruh nyata terhadap parameter yang diamati antara lain pertambahan tinggi tanaman, pertambahan diameter batang dan pertambahan jumlah daun.

Djuarnani N, Kristian, Budi SS. 2005. Cara Cepat Membuat Kompos. Agro Media Pustaka.

Depok Eko, dkk. 2013.Budidaya Tanaman Karet. Penebar Swadaya. Jakarta. 56 hal.

Hakim, M. 2005. Mengubah Sampah Menjadi Kompos. Pikiran Rakyat 20 Oktober 2005.

Harjadi, S. S. 2003.Pengantar Agronomi. Wiramedia Pustaka Utama. Jakarta. 
Indriani, YH. 1999. Membuat Kompos Secara Kilat. Penebar Swadaya. Jakarta.

Kemenprin. $2012 . \quad$ karet; http://www.kemenperin.go.id/artikel/1169 8/Perbesar-Serapan-Karet-Alam-di-PasarDomestik

Lingga, P. 2004. Petunjuk Penggunaan Pupuk. Penebar Swadaya. Jakarta. $43 \mathrm{hlm}$.

Musnawar dan Ismawati. E. 2005.Pupuk Organik Cair dan Padat, Pembuatan dan Aplikasi. Swadaya. Jakarta.

Pranata, Ayub. S. 2004. Pupuk Organik Cair : Aplikasi dan Manfaatnya. Agromedia Pustaka: Jakarta.

Santoso, H. B. 2005. Pupuk Organik. Kanisius.Yogyakarta.
Setyamidjaja, D. 1993. Karet. Kanisius. Yogyakarta.

Simamora dan Salundik. 2006. Meningkatkan Kualiats Kompos. Agromedia Pustaka. Jakarta.

Steel RGD, Torrie JH. 1991. Prinsip dan Prosedur Statistika. Jakarta: PT.Gramedia.

Sukamto. 1977. Pemupukan Melalui Daun. Warta BPTK Gambung. Bandung

Sutedjo. M. M. 2006. Pupuk Dan Cara Pemupukan. Bhineka Cipta. Jakarta.

Tim Penulis PS. 2008. Panduan Lengkap Karet. Penebar Swadaya. Jakarta.

Wunungga. 2009. Pengaruh Macam dan Interval Waktu Pemberian Pupuk Lengkap Cair Terhadap Pertumbuhan dan Bibit Kakao (Theobroma cacao) 